Portland State University

PDXScholar

\title{
Desegregation and Multiculturalism in the Portland Public Schools
}

\author{
Ethan Johnson \\ Portland State University, ejohns@pdx.edu \\ Felicia Williams \\ Portland Downtown Neighborhood Association
}

Follow this and additional works at: https://pdxscholar.library.pdx.edu/black_studies_fac

Part of the Education Commons, and the Race, Ethnicity and Post-Colonial Studies Commons Let us know how access to this document benefits you.

\section{Citation Details}

Johnson, E. \& William, F. (2010). "Desegregation and Multiculturalism in the Portland Public Schools." Oregon Historical Quarterly, Vol. 111, No. 1: 6-37.

This Article is brought to you for free and open access. It has been accepted for inclusion in Black Studies Faculty Publications and Presentations by an authorized administrator of PDXScholar. Please contact us if we can make this document more accessible: pdxscholar@pdx.edu. 


\section{ETHAN JOHNSON AND FELICIA WILLIAMS}

\section{Desegregation and Multiculturalism in the Portland Public Schools}

\section{HELEN MARIE CASEY'S BOOKLET Portland's Compromise: the Colored}

School, 1867-1872 recounts the story of William Brown, an African-American resident of Portland, Oregon, and his role in the first and only case of official segregation of African-American children in Portland Public Schools (PPS) in 1867. After unsuccessfully trying to enroll his children in one of Portland's only two public elementary schools, Brown appealed to the school board, including directors Josiah Failing, W.S. Ladd, and E.D. Shattuck. Again, his children were denied access. The board of directors explained their resistance to integrated schools by saying: "If we admit them [African-American children], then next year we will have no money to run the schools." According to Casey, the directors were "afraid to provoke the taxpayers and rouse their ire." ${ }^{\prime}$ ather than attempting such a politically "risky" effort, the school board eventually allocated $\$ 800-\$ 765$ more than it had offered prior to Brown's threat of a lawsuit — for a segregated school at the corner Southwest Fourth and Columbia. Twenty-six African-American students, twenty-one boys and five girls - many of whom had previously attempted to attend another public, or "free," school in Portland but had been denied - enrolled in the school. The continued existence of the "Colored School" was constantly in question at annual school meetings. Funding for the school was abolished in 1872 , and the next year, thirty African-American children were admitted to the newly integrated PPS.

Since Oregon acquired statehood in 1859, the relationship between African Americans and public education in the city of Portland has been complex and closely correlated to the broader racial dynamics of the city, 


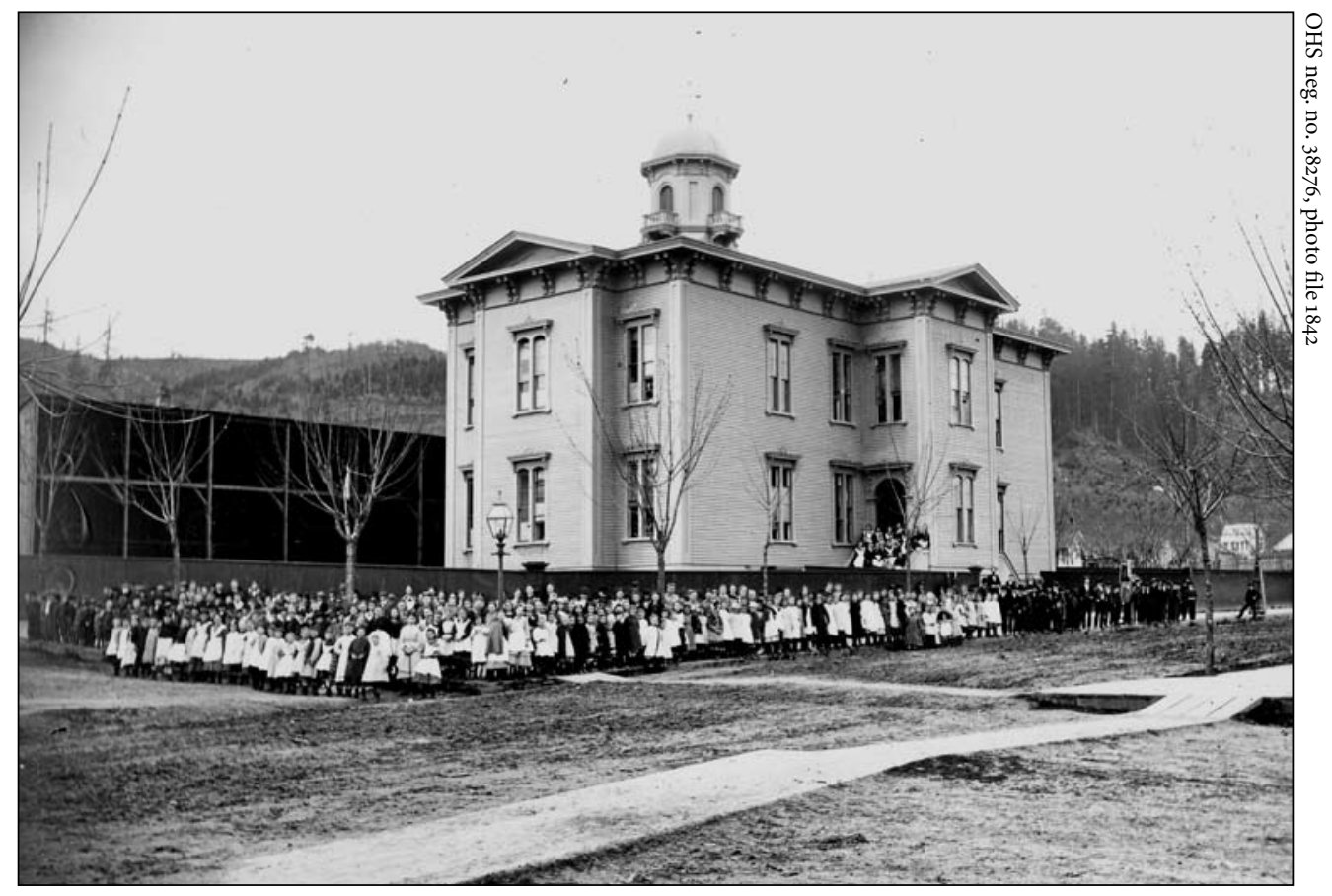

Harrison Street school, shown here in about 1880, was in operation when William Brown asked for his children to be admitted to Portland's public schools. The city's schools were officially integrated in 1873.

state, and nation. With three "Black exclusion laws" to its name, including one written into the original state constitution, Oregon was established in the late nineteenth century as the most formidable and dangerous place outside the South for an African-American person to call home. Oregon was never a slave state; however, historical records of lynchings, as well as institutionally denied or limited rights and access, effectively dispute the argument that it was a "free state" either. ${ }^{2}$

The pattern of response from Portland's Euro-American-dominated public school system to the struggles of African Americans for desegregation and quality education stems from the historic racial dynamics of Oregon and, more specifically, of Portland. This pattern tends to echo the story of the Colored School. There is often initial resistance to change on any level, sometimes explained as being due to the system's fear of taking "political risks" such as alienating Euro-American citizens in Portland's subtly contentious racial atmosphere. Commonly, this is followed by persistent efforts of community members and groups — for example, 
William Brown threatening to bring a lawsuit against the school board eventually leading to the institution of a new policy, usually fulfilling only a portion of those community members' goals. What typically ensues is a process of negotiation and occasional undermining of the new policy by parts of the community, the local and occasionally the national media, and even PPS and the Board of Education itself, as was the case with the Colored School. In the 140 years since the closing of the Colored School, Portland's African-American community has continued to struggle to attain quality education for its children, an effort that has been mirrored by the national fights for educational equity, including desegregation and multicultural education.

This study explores the relationship between PPS and the city's AfricanAmerican residents, especially having to do with policy decisions about desegregation and multiculturalism. These efforts can be broken down into three broad time frames. The first is from 1859 to 1941, the period stretching from Oregon's initiation into statehood through the beginning of World War II. The second time frame covers from 1941 to 1980, as PPS became far more segregated because of racially restrictive housing policies; conflicts over desegregation characterize this period. The rise of the Black United Front (BUF) in the late 1970s signals the beginning of the third period. The BUF's efforts led to the end of busing and the passage of the Comprehensive Desegregation Plan, which emphasized quality and multicultural education over desegregation. Examining the relationship between various institutions and organizations representing Portland's African-American community and PPS gives a nuanced perspective of how educational policy decisions were affected by racial tensions and conflicts in one West Coast city and fills a gap in the literature. ${ }^{3}$

\section{9-1941}

Between 1859 and 1941, there was minimal change in either the racial composition of Portland or the public school system's relationship with the small number of African Americans living in the city. Records indicate that African Americans first arrived in Oregon in 1788 and in Portland by 1850. City reports estimate that Portland's African-American population in 1860 was about $130 .{ }^{4}$ While a lack of economic possibilities may have contributed to the small population of non-European racial and cultural groups, it appears that racism played an equally if not more important role in contributing to the small minority population in Portland. Oregon was the only state to be admitted to the union with a Black exclusion clause in its constitution. ${ }^{5}$ In addition to the exclusionary clause, the state also passed limits on the Chinese and Japanese populations during this period, and the Black exclusion laws remained in the state's constitution until 1926. Further evidence of the 
unwelcoming attitude Oregon presented to African Americans is revealed in the Oregon legislature's 1869 rescission of its initial ratification of the Fourteenth Amendment; it did not re-ratify the amendment until $1973 .{ }^{6}$

From 1900 to 1920, the African-American population in Portland ranged from 775 to $1556 .^{7}$ The arrival of the railroad and associated job opportunities in Portland established the city as the center of the African-American population in Oregon. The Portland Hotel was the second largest employer of African Americans, who hotel owners recruited from Georgia. ${ }^{8}$ Nevertheless, throughout this period, the Japanese and Chinese communities each comprised a larger proportion of the population in Portland than African Americans. Historian Quintard Taylor, in his study of the experiences of African Americans in Seattle, has demonstrated that the relatively large size of these communities deflected attention away from African Americans, resulting in the creation of fewer exclusionary policies toward them. ${ }^{9}$ In other words, African Americans did not always represent the primary target of racial discrimination. Some of the exclusionary and anti-miscegenation laws passed in Oregon, for example, included those targeting Chinese, Native Americans, and Japanese people. In addition, during the 1880 s, there were riots in Portland and Tacoma in which Euro-Americans attempted to remove the Chinese from these cities because of the economic threat they posed. ${ }^{10}$ While the racial and cultural diversity of Portland may have at times kept African Americans from being the main target of exclusionary practices, it seems the overall small population of the community simply did not pose enough of a threat to the majority Euro-American population for the development of official racial educational policies.

Other than the Colored School episode, there is little evidence that African Americans experienced legal forms of discrimination in the nineteenth century, but the beginning of the twentieth century was a different matter. In 1906, African-American men could vote and serve as jurors, and AfricanAmerican children could attend school with Euro-American children. In addition, both theaters and restaurants did not have separate seating areas based on race, although African Americans knew where they could and could not go. ${ }^{11}$ With the growth of European immigrants in Portland at the start of the twentieth century, African Americans faced more explicit forms of discrimination. Unions excluded African Americans, and hotels, restaurants, and theaters frequently refused to serve African Americans. According to urban studies professor Karen Gibson, "in 1919, the Portland Realty Board adopted a rule declaring it unethical for an agent to sell property to either Negro or Chinese people in a White neighborhood. The Realtors felt it was best to declare a section of the city for them so that the projected decrease in property values could be contained within limited special boundaries." ${ }^{12}$ 


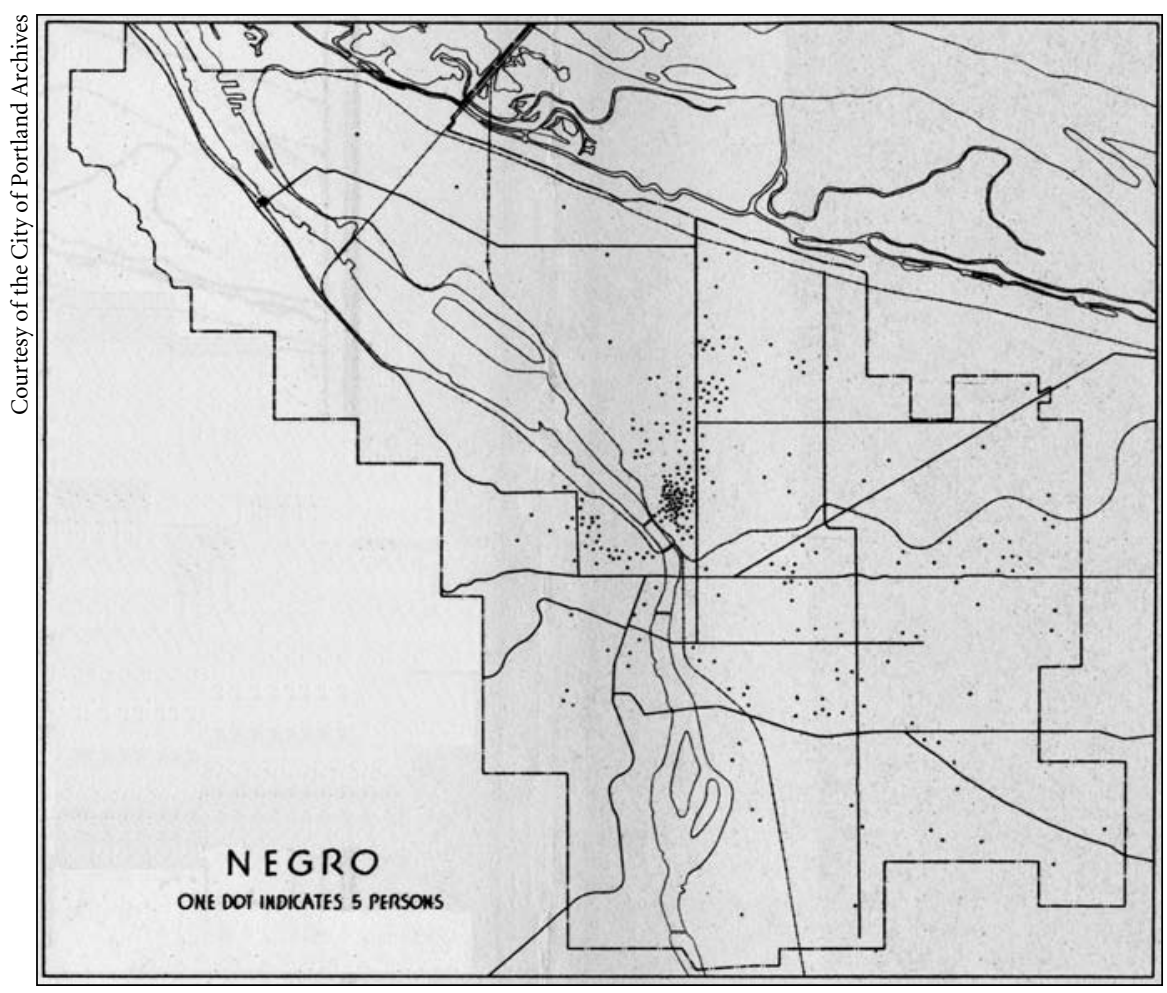

This detail from a 1936 map titled "The Neighborhood Pattern of the City as Defined by Foreign-Born and Racial Occupancy" demonstrates that African Americans lived throughout Portland, but there was a growing concentration in the Albina district of the city.

This practice started the process of establishing the Albina district as an African-American neighborhood. ${ }^{13}$

Kathryn Hall Bogle's 1937 Oregonian article "An American Negro Speaks of Color" details her childhood experiences with racism in the schools. Bogle's father worked on the railroads and she attended eighteen different schools in Oregon, Washington, California, Montana, and Minnesota before finally graduating from high school in Portland, Oregon. She remembers offensive language used by guest speakers, who frequently made African Americans the butt of jokes, and textbooks that limited the portrayals of African Americans primarily to slavery coupled with caricatures during the Reconstruction era. She describes history classes as being the most humiliating: 
During this period perhaps no rocks are thrown by hand, but there are subtle omissions, exceptions, and other differences made that wound the spirit. No attempt is made to help him to real pride of his own race. Rather, outside of his home, he is bombarded by assaults and propaganda against his race. ${ }^{14}$

In two Oregon history textbooks from 1937 and 1942, there is a nearly complete absence of the experiences of African Americans, Chinese, and Japanese people. ${ }^{15}$

Since the closure of the Colored School in 1872, de jure segregation in public education has not been practiced in the city of Portland. Between 1859 and 1940, the African-American population of Oregon grew very little; however, due to labor migration during World War II, the number of African-American residents throughout the state expanded from 1,931 in 1940 to approximately 23,000 in 1945 , resulting in a profound impact on the relationship between Portland Public Schools and the city's AfricanAmerican population. ${ }^{16}$

\section{SHIFTING POPULATION DYNAMICS AND THE CIVIL RIGHTS MOVEMENT, 1941-1980}

Many African Americans moved West during World War II because of economic opportunities, including shipbuilding and related industries associated with the war. As a result, the African-American population in Oregon increased tenfold, with most people located in or near Portland. Restrictive housing covenants developed by the Portland Realty Board and Euro-American Portlanders' resistance to African Americans moving into other parts of the city directed many new African-American residents to the Albina district. A statement representing five hundred Euro-American Portland residents declared:

If it is necessary to bring large numbers of Negro Workers, locate them on the edge of the city.... It would be much better for all concerned. If they are allowed to fan out through the city it soon will be necessary to station a policeman on every corner. ${ }^{17}$

Because the Housing Authority of Portland refused to build enough housing for defense contract workers, Kaiser Steel, the primary shipbuilding company in Portland, bought land in 1942 just north of Portland and south of the Columbia River to develop housing for its workers. ${ }^{18}$ As a result of wartime industry jobs, this defense housing project, named Vanport for its location between Vancouver and Portland, became the second largest city in the state. It should be noted that while there was segregation within the Vanport housing project, African-American and Euro-American children attended school together, and Vanport hired the first African Americans to 
teach in the Oregon public schools. On May 30, 1948, Vanport flooded, and approximately 16,000 people, more than one third of them African American, were forced out of their homes. Other defense housing sites were bulldozed in the late 1940s; consequently, thousands of individuals and families had few other options than to move to an already overcrowded Portland. ${ }^{19}$

By 1950, less than half of the wartime African-American population remained in Portland. This was largely due to the lack of housing and employment opportunities coupled with Portland's leadership actively discouraging them from staying. ${ }^{20}$ According to the documentary Local Color, "Portland's mayor, Earl Riley, had openly declared the city could absorb only a minimum of Negroes without upsetting its regular life." ${ }^{21}$ After the flood of Vanport and demolition of other defense housing, neighborhood associations, realtors, and banks employed various methods to coerce African Americans into the Albina district located in the Northeast quadrant of Portland, where the majority of African Americans in Portland already lived. As African Americans moved into the district, Euro-Americans moved out. Gibson states:

During the 1950s, Albina lost one-third of its population and experienced significant racial turnover as White residents left en masse for the suburbs and Black residents moved into Albina from temporary war housing. By decade's end, there were 23,00o fewer White and 7,300 more Black residents. ${ }^{22}$

By 1960, approximately 80 percent of the African Americans in Portland lived in the Albina district. ${ }^{23}$ Portland's residential segregation shaped school enrollment patterns, and the Albina district harbored the majority of schools with disproportionate percentages of African-American students. In 1945, for example, 38 percent of the students at Eliot Elementary were African American, but by 1957 , they comprised 80 percent of the student body. ${ }^{24}$ This is especially striking because African Americans only made up 2 percent of Portland's total population. ${ }^{25}$

Bolstered by recent political and economic gains, such as increased job opportunities during World War II and the 1954 Brown vs. Board of Education U.S. Supreme Court decision, African Americans across the nation began to challenge school segregation. School segregation became arguably one of the most contentious issues facing PPS and the city throughout the 1960 s and 1970s. Initially after the passing of the Brown Supreme Court decision, PPS took the position that "it had a policy of equal education and that it would take no action regarding segregation in Portland Public Schools." ${ }^{26}$ In 1962, the National Association for the Advancement of Colored People (NAACP) publicly accused the district of passively allowing the patterns of segregation to persist, and that same year, the national headquarters 
of the NAACP administered a study of PPS. ${ }^{27}$ The NAACP recommended pairing (the coupling of majority-African American with majority-EuroAmerican schools through the assignment of students to both schools at different points throughout their academic careers); the construction of new schools situated between racially isolated neighborhoods; closing Boise and Eliot schools; redrawing school district lines; reassigning children to other schools; and the use of busing to alleviate racial segregation. ${ }^{28}$ Rather than implement the NAACP's suggestions, PPS decided to sponsor its own study, Race and Equal Educational Opportunity in Portland's Public Schools, also known as the Schwab Report, to assess racial isolation and racial disparities in academic achievement. Various members of Portland's African-American community saw this move as a way of ignoring the problem..$^{29}$

After eighteen months of study, the extensive 1964 Schwab Report concluded that racial disparity in education did exist and made over forty recommendations. These addressed compensatory education, a district transfer policy, multicultural education, special education, and external factors impacting the school, such as unions, government organizations, and private businesses. The Schwab Report recommended keeping the neighborhood school model — which did nothing to alleviate the problems caused by housing segregation — and advised against busing. In addition, the report recommended the voluntary Administrative Transfer Program (ATP), which allowed students to transfer to other schools provided there was room but required parents to bear the responsibility for transportation. Ultimately, these policies did little to address the NAACP's concerns about segregation. Portland NAACP president Mayfield K. Webb commented on the Schwab committee's recommendations: "It's amazing to us that this blue ribbon committee can close its eyes completely to resolving the problem on the local situation." ${ }^{30}$

Analysis of the Schwab Report reveals that its members acknowledged the significance of historic and persistent racial inequality and discrimination in Portland. In one section, the report highlights discrepancies in enrollment patterns within special education programs. At Jefferson High School, for example, while African-American students made up approximately 25 percent of the school population, 75 percent of the students in the special education program were African American. Moreover, in the 1963-1964 school year, 7 percent of Jefferson High School's students were classified as "mentally retarded"; of the 162 students in the program, 122 of them were African American. Additionally, PPS had designated 212 of Portland's 1,181 African American high school students (approximately 18 percent) as mentally retarded. ${ }^{31}$ The Schwab Report expressed deep concern for the disproportionate numbers of African-American students in the mentally retarded 


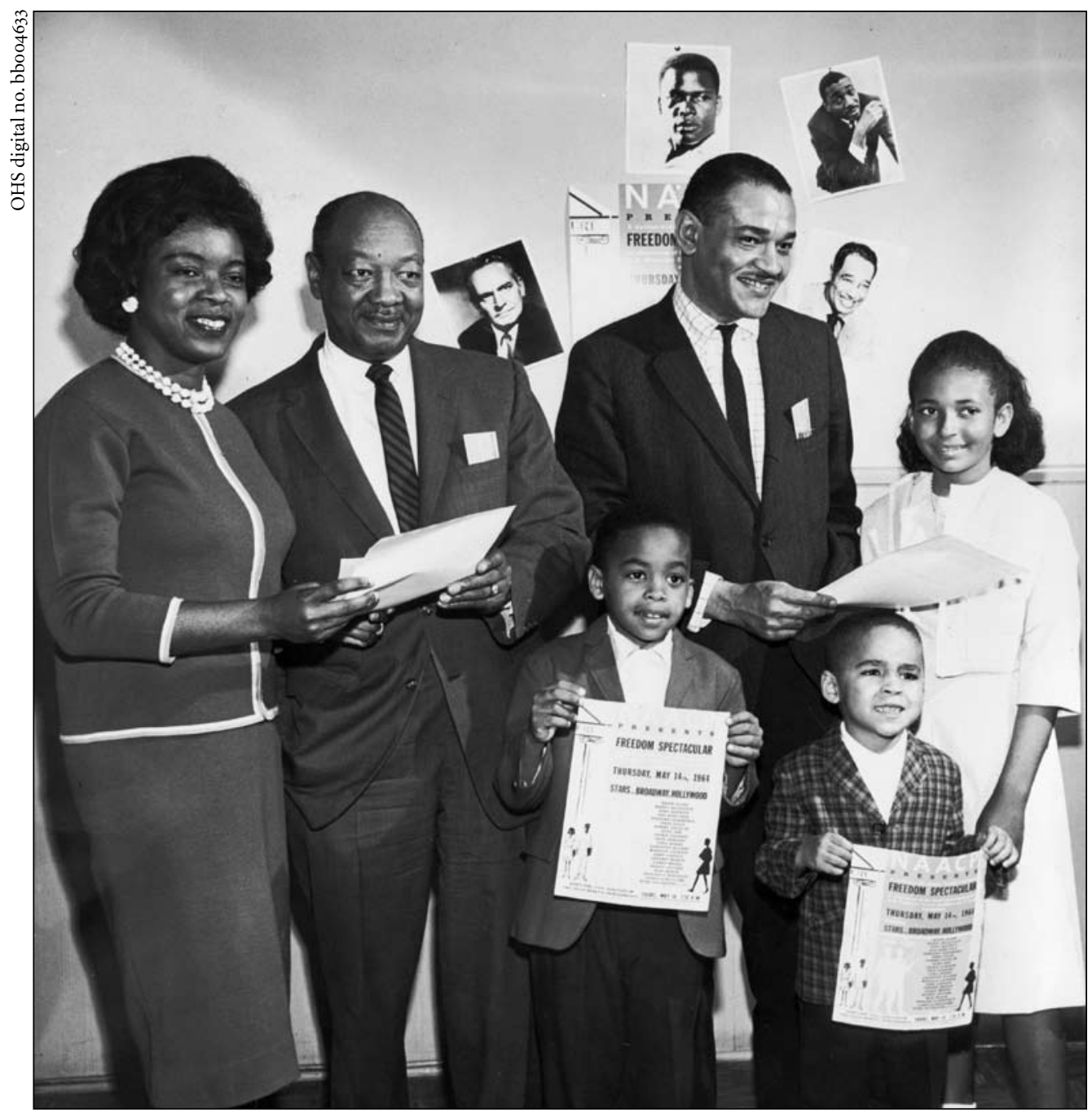

Portland NAACP President Mayfield Webb (right, with three of his seven children) celebrates the organization's fiftieth anniversary with Ulysses Plummer and an unidentified woman in 1964. Webb was a vocal critic of PPS' failure to desegregate the schools.

(MR) program and recommended "a thorough re-evaluation of the special achievement program by qualified disinterested parties ... and constant effort to provide a maximum of education to MR students so that initial cultural deficiencies will not be made irreversible" [emphasis added]. ${ }^{32}$

Another way the Schwab Report explicitly built race into policy recommendations was its multicultural education curriculum initiative. Proposed 
curriculum changes in the section titled "Removal of Prejudice" called for changes in history and social studies classes at both the elementary and high school level, including developing teaching units that would "emphasize the role of majorities and minorities in American life." It continued: "In these classes a major effort should be made to point out the importance of the contributions of different races to our society, the significance and the consequences of racial conflict and the factors which give rise to such conflict." ${ }^{33}$ Although these multicultural curriculum policies were adopted, they never fully made their way into practice.

While the report recognized that institutional racism was a major factor in Portland and shaped the educational opportunities of African-American youth in PPS, its overarching theme - evident in key policy recommendations - conflated race with class and focused on the perceived cultural deficiencies of African-American students. This particular perspective was based on the cultural deficit model, which relied on the idea that if a child's social, cultural, or economic home life or background was either "depraved" or "deprived," then the student would have difficulty succeeding academically and socially. ${ }^{34}$ While the NAACP had suggested busing to alleviate segregation, for example, the Schwab committee provided the following reasons for opposing busing:

We also fear the probable result of taking a small group of Negro children of deplorable home background out of an Albina school and isolating it in an all-white middle or upper class school where the Negro children may be two or three grade levels behind their new peers, and where they will be regarded as strangers, outsiders, subjected to ridicule and paternalism..$^{35}$

Here, while the race of the children was noted, it is their social class background that was emphasized. The authors' objection to busing generalized about African-American youth in Albina as coming from a "deplorable home background." In another section of the report, committee members blamed African Americans for their failure to achieve in school, thus ignoring persistent structural racism. They observed: "Still, the Negro in America has suffered a tradition of subservience and discrimination which has tended to lower motivation generally, and especially in the educational system. ${ }^{36}$ Committee members believed that home life, education level, and social and cultural differences had the greatest impact on African-American students' educational experience, but they still assumed that most African Americans fell into the deprived category, citing socioeconomic factors as being more important than race in their opposition to busing. By rejecting busing for socioeconomic and cultural reasons, PPS avoided the issues of racial desegregation and busing entirely. The report does not consider the 
NAACP pairing proposal, which would have bused both African-American and Euro-American students.

The conflation of race and class becomes even more apparent in the report's recommendation of compensatory education. Again working from a socioeconomic cultural deficit model, the report suggests compensatory education programs for both poor Euro-American and poor African-American youth; however, examination of the report reveals that there was no attempt to study cultural deficiency in predominantly Euro-American neighborhoods. The focus was strictly on African Americans in the Albina neighborhood.

The Portland NAACP branch condemned the Schwab Report based on several factors, including the emphasis on cultural deficiency and failure to address desegregation. Portland's NAACP representative William McClendon criticized the report because it "overemphasize[d] the negative aspects of Black family life, poverty, fear and social rejections." ${ }^{37}$ The NAACP also charged the school board with promoting a "separate but equal policy." ${ }^{8}$ The school board adopted the report in full, including its policy recommendations; however, PPS failed to follow through on some of the recommendations, leading to further opposition from the African-American community. Portland NAACP President Mayfield K. Webb noted that groups who initially supported the report quickly noticed the lack of enforcement: "They believed it would be a first step, but now see no follow up or second step."39

The Model Schools Program (MSP) was the cornerstone of the Schwab Report. Its purpose was to provide compensatory education at the elementary level in order to improve academic achievement through smaller class sizes, classroom aides, and pre-schools. Additionally, the report emphasized the need for school nurses and psychologists. Ten schools were recommended for the MSP: Eliot, Boise, Highland (now King), Buckman, Holladay, Humboldt, Whitman, George, Woodlawn, and Irvington. The report wanted to include "at least two predominantly Negro enrollment schools and at least two predominantly White enrollment schools" within the MSP. ${ }^{40}$ An investigation of the program reveals that while the Schwab Report attempted to conflate race with class, in its implementation, PPS proved it was all about race. PPS dropped two of the three overwhelmingly Euro-American schools - George and Whitman - that were initially proposed in the Schwab Report and added Sabin Elementary, which had a large African-American student body. All but one of the MSP schools were located in inner-Northeast Portland, and the majority of the nine schools had African-American student populations that were over 65 percent of the student body (see Table 1). ${ }^{41}$

There were positive aspects of the MSP. The schools received on average five hundred more dollars per student than other Portland public schools. ${ }^{42}$ 


\begin{tabular}{|c|c|c|c|}
\hline \multicolumn{4}{|c|}{$\begin{array}{c}\text { Table 1: Model Schools Program } \\
\text { And African-American Student Enrollment }\end{array}$} \\
\hline Model School & $\begin{array}{l}\text { Total Enrollment } \\
1964-65 \text { School Year }\end{array}$ & $\begin{array}{l}\text { African-American } \\
\text { Enrollment }\end{array}$ & $\begin{array}{l}\text { Percent African } \\
\text { American }\end{array}$ \\
\hline Boise & 941 & 899 & 96 \\
\hline Buckman & 706 & 11 & 2 \\
\hline Eliot & 344 & 325 & 94 \\
\hline Highland (King) & 1,013 & 884 & 87 \\
\hline Holladay & 301 & 203 & 67 \\
\hline Humboldt & 352 & 324 & 92 \\
\hline Irvington & 757 & 366 & 48 \\
\hline Sabin & 683 & 224 & 33 \\
\hline Woodlawn & 805 & 218 & 27 \\
\hline \multicolumn{4}{|c|}{ SOURCE: Schwab Report (see note 30), prepared by authors } \\
\hline
\end{tabular}

One of the goals of the MSP was to reduce class sizes, and many of these resources were directed at hiring more staff. Class sizes were also reduced by "White flight" - Euro-Americans moving out of the city — and the demolition of housing stock in the area. ${ }^{43}$ It is difficult to assess the success of the MSP because of the lack of a systematic and comprehensive evaluation process, but what is evident is that during the five years of its implementation, stability in critical areas was achieved. Academic achievement, for example, while not statistically significant, was rising; teacher turnover was reduced dramatically; and there were clear indications that rates of disciplinary referrals and attendance problems dropped. Other factors, such as the Model Cities program, which addressed housing and employment discrimination in Albina, also likely contributed to the increasing stability in the schools. ${ }^{44}$

Overshadowing this relative stability was the growing level of segregation African-American students experienced - exactly what the NAACP said the MSP would do. The perception of the MSP by the African-American community was revealed in the Oregon Advance Times, one of Portland's African-American newspapers, which frequently criticized the program for failing to hire African-American administrators and for being unresponsive 
to educational innovations. One editorial expressed disgust with the quality of education children were receiving: "We cannot help but wonder how long the parents of the children in the model schools will go along with the program foisted upon them by the school administration. At best, it provides very poor baby sitting services. Certainly the parents of these youngsters should expect far more from the school system." 45

By 1968, the concentration of African-American students to a few schools was a serious concern for the school board. A 1968 Portland City Club Bulletin, Problems of Racial Justice in Portland, notes: "Of the 4,800 Negro elementary pupils, 73 per cent $(3,500)$ are enrolled in nine of the 94 elementary schools.... Four schools are over 90 per cent Negro (Boise, 93 per cent; Highland [now King], 94 per cent; Eliot, 92 per cent; Humboldt, 91 per cent." All four were part of the Model Schools Program. The pattern was repeated at the high school level, with the majority of African-American students attending Jefferson High School, where they made up 37.4 percent of the student population..$^{46}$ When the MSP ended in 1972, racial isolation was largely unchanged in the schools involved. The percentages of AfricanAmerican student populations at the Model Schools in the 1971-1972 school year were: Boise 96; Buckman 18; Eliot 58; Holladay 50; Humboldt 84; Irvington 63; King (Highland) 91; Sabin 64; and Woodlawn 48. ${ }^{47}$

Racial conflict in the schools was also becoming harder to ignore during the 1960s. The first reports of racial strife at Jefferson High School appeared in 1964, and racial tension was common in 1966 and 1967, with reports indicating that teachers and students of all races were involved. ${ }^{8}$ Rev. Martin Luther King, Jr's assassination on Thursday, April 4, 1968, brought these issues to the forefront for PPS. The school district considered closing Jefferson High School on April 5, but decided against it, only to have the school's principal call for its closure following student unrest. ${ }^{49}$ Over the weekend, the pressures built and PPS opted to defuse the situation by keeping schools closed on Monday April 8, and on Tuesday morning, April 9. Mayor Terry Schrunk sent extra police officers into Jefferson High School, and the racial tensions continued to simmer throughout the rest of the school year. The Portland Public Schools District publicly floated the idea of closing Jefferson High School the following year..$^{50}$

After national race riots during 1967, the federal government appointed the Kerner Commission to study racial problems in the United States. Their assessment, the Kerner Report, recommended that cities end racial isolation, especially in education. Portland experienced a small riot in 1967 in Irving Park, but the damage was limited. Still, economic marginalization, social alienation, and institutional racism identified by the Kerner Report as causes of the 1967 riots continued to be present in Portland and contributed to the 
frustration that many of the city's African-American residents felt. A roving reporter for the Oregon Advance Times ran a regular series asking Albina's African-American residents what they thought Albina needed, and those interviewed frequently identified better schools, jobs, housing, and recreation centers for youth. Richard G. Wilburn voiced a typical response: "Our children are the most important product of our community. We need more recreation for children and we certainly need better schools. We don't have enough teachers and sooner or later the city will wake up." ${ }^{51}$ When asked by the reporter if there would be a riot in the upcoming summer of 1968 in Portland, many people expressed belief that there would, but they also hoped it could be avoided. When the Kerner Report was published, the Advance Times responded with an editorial titled "Problem Exists Here, Too," which called on city leaders to do something about racism in Portland: "We hope our own mayor will review this report and will be among those mayors that are tuned in and recognizing that a problem exists that calls for immediate action to wipe out the cause - the cause being white racism." ${ }^{2}$ The city did not take action, and in 1969, there was a large riot on Union Avenue (today's Martin Luther King, Jr., Boulevard) that lasted four days and highlighted the racial problems that existed in Portland. Newspaper reports about the riots indicate that police brutality and harassment of African Americans at Lidio's Drive-In on Northeast Union and Shaver was the flash point, but many of the same tensions that had caused the national long, hot summer of 1967 were also clearly present in Portland..$^{53}$

In the aftermath of the Union Avenue riot, the city agreed to be more proactive in reducing the underlying causes. One of their focus areas was desegregating the schools. In the summer of 1969, PPS hired Superintendent Robert Blanchard, and he quickly changed the direction of PPS with regard to desegregation through his contentious plan, "Portland Schools for the Seventies." ${ }^{54}$

The Schools for the Seventies plan had several main components, all aimed at desegregation. First, the school district would be decentralized and reorganized into three administrative and attendance districts with new boundaries that effectively split the African-American population. Second, middle schools would replace the $\mathrm{K}-8$ (kindergarten through eighth grade) configuration used in Portland grade schools, but no middle schools were planned for the Albina area. Third, Early Childhood Education Centers (ECECs) would be established in the Albina area, which would theoretically encourage Euro-American parents to send their children into a predominantly African-American neighborhood for schooling; busing was provided for children attending ECECs. Significantly, all of the MSP schools became ECECs, which resulted in only one Albina district school having grades six through eight. By 1977, only the 
Eliot school served those grades, which meant that approximately 600 students were forced to bus to middle schools outside of the Albina neighborhood. ${ }^{5}$ Finally, the Administrative Transfer Program (ATP), which was amended to include busing and recruitment of African-American students, was accelerated, and the plan established a racial quota of 25 percent for minority students in schools..$^{56}$

Several U.S. Supreme Court decisions in the late 1960 s and early 1970 s provided the rationale and legal basis for Blanchard's Schools for the Seventies. In its 1968 decision Green v. County School Board, the Court ruled that "freedom of choice" plans, such as the original Administrative Transfer Program advocated in the Schwab Report, were inadequate. The Court also laid out

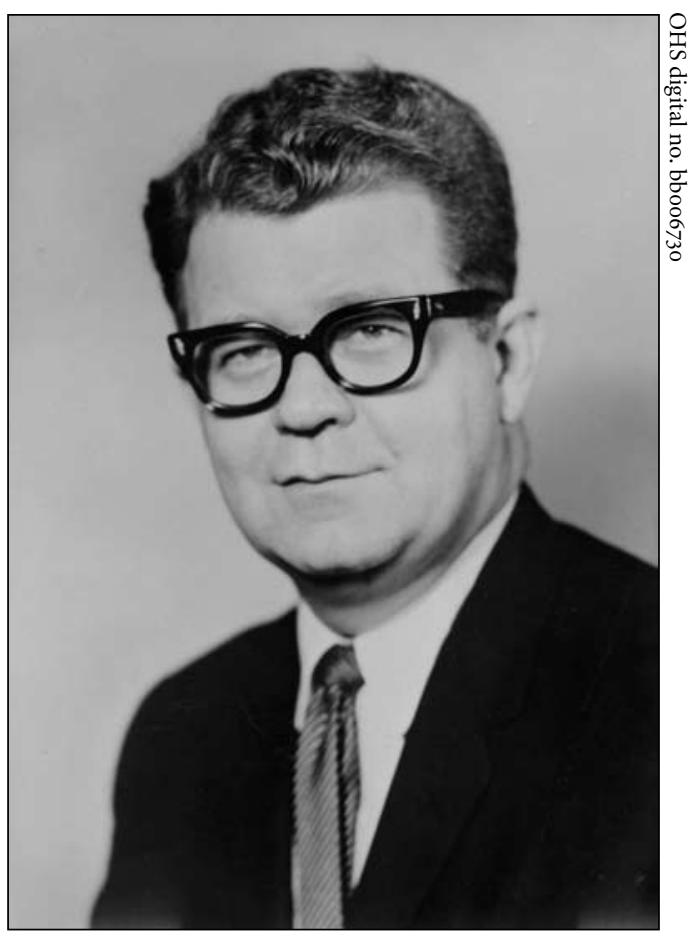

Superintendent Robert Blanchard served from 1969 to 1980 . He implemented the contentious "Schools for the Seventies" plan, which called for widespread busing to desegregate the schools. specific plans, including rearranging district boundaries to insure minority representation in schools. The following year, the Supreme Court decided in U.S. v. Montgomery County Board of Education that racial quotas were an appropriate tool to use in desegregation plans. Finally, in Swann v. Charlotte-Mecklenburg (1971), the Court decreed segregation resulting from residential patterns constituted past misconduct, attendance zones had to be redrawn, and implementation of busing could be used as a remedy. All of these decisions affected PPS' efforts at desegregation.

The ATP and the redrawing of school boundaries were the easiest ways for the school board to remain compliant with the Supreme Court's decisions. They also affected the least number of Euro-Americans, so the burden of desegregation fell primarily on Portland's African-American residents. The ATP was originally implemented in 1964 and had a negligible impact on racial isolation. Portland started busing Albina students to suburban schools in 1968, but the number of students participating in the suburban 
transfer program never reached much higher than one hundred. Blanchard accelerated the ATP during the 1970s, and approximately two-thirds of the students bused were African American (see Table 2). ${ }^{77}$ According to a staff report by the U.S. Commission on Civil Rights, by 1975, approximately 22 percent $(2,346)$ of Portland's total African-American student population was bused, compared to the 484 Euro-American students who participated in the ATP that same year..$^{8}$ When the suburban transfer program started in the late 1960s, many residents in the African-American community supported busing their children. Mrs. S.O. Broadus, a one-time PTA president at Boise Elementary, gave what was considered by the Oregon Advance Times a typical response: "I am very pleased. I feel that they will get more out of school by this kind of action." 59

Reverend W.G. Hardy recently reflected on the impact of busing on both African-American students and the community as a whole:

WH: The African-American community was really divided and they talked about segregation and the powers that be thought it would be a great idea to take all the AfricanAmericans, put them on a bus and bus them out to schools where they had superior books, superior equipment, better teachers.... When you take the children out of the community and take them somewhere it appears to be better and bring them back to the community it doesn't necessarily fix the problem. It kind of exacerbates it and lets you know someone else has a better lifestyle... They thought it would have been more effective if you would have had an exchange and bused kids from both areas ...

JW: How did it affect your friends from your community? Did you ever talk to them about that?

WH: It's amazing because I have talked to both whites and blacks and it was devastating. The adults had no idea how traumatic it was for children to integrate into a culture to navigate through that, to develop relationships and then be torn apart.... Now when the black and white kid go amongst all black the black kid now has to act like they don't own the white friend. So the white kid has to figure out, well wait a minute, your black friends came around and now we are not friends. Why the change in behavior? And the black and the white can go amongst a lot of whites and the white person would then change their behavior to adapt the dominant culture. And the black person is trying to figure out now wait a minute, we were friends just a minute ago and now you are laughing at a racist joke. So, you had this going on both sides. And the children knew that all of us were trying to navigate through all of that. ${ }^{60}$

Hardy's observations about busing were echoed in Ray Rist's seminal work on Portland's ATP, The Invisible Children. Rist found that students had difficulty adjusting to their new schools and that teachers in the receiving schools were inadequately prepared to deal with the new students. Additionally, because their numbers were so low, teachers and administrators could 


\begin{tabular}{|c|c|c|c|c|}
\hline \multicolumn{5}{|c|}{ TABle 2: Busing AND Administrative Transfers } \\
\hline Year & $\begin{array}{l}\text { Suburban } \\
\text { Transfers }\end{array}$ & $\begin{array}{l}\text { Elementary In- } \\
\text { District Transfers }\end{array}$ & $\begin{array}{l}\text { Secondary In- } \\
\text { District Transfers }\end{array}$ & $\begin{array}{c}\text { Total Number of } \\
\text { Transfers }\end{array}$ \\
\hline 1964 & - & 250 & - & 250 \\
\hline 1965 & - & 359 & - & 359 \\
\hline 1966 & - & 388 & - & 388 \\
\hline 1967 & - & 424 & - & 424 \\
\hline 1968 & 98 & 507 & - & 605 \\
\hline 1969 & 113 & 532 & - & 645 \\
\hline 1971 & 100 & 475 & 150 & 725 \\
\hline 1972 & 105 & 1,262 & 319 & 1,686 \\
\hline 1973 & 81 & 1,491 & 455 & 2,027 \\
\hline 1974 & 113 & 1,557 & 489 & 2,159 \\
\hline 1975 & 113 & 1,472 & 489 & 2,074 \\
\hline 1976 & 118 & 1,708 & 755 & 2,581 \\
\hline 1977 & 93 & 2,009 & 786 & 2,888 \\
\hline \multicolumn{5}{|c|}{$\begin{array}{l}\text { Noтв: All suburban transfer students were African American. Prior to 1972, the Administrative Transfer Program } \\
\text { (in-district) was open to all students, but after that year, Superintendent Blanchard focused on recruiting African- } \\
\text { American families for desegregation busing. } \\
\text { SouRCE: Portland Public Schools Records Management, Articles: "Racial Balance" n.d.:"Racial Integration Programs } \\
\text { for the Portland Public Schools" n.d. No specific numbers regarding race were available, but other documents indicate } \\
\text { that, depending on the year, approximately two-thirds to } 9 \text { o percent of students bused were African American. Table, } \\
\text { prepared by authors, is intended to demonstrate Superintendent Blanchard's acceleration of desegregation in PPS. }\end{array}$} \\
\hline
\end{tabular}

effectively marginalize the African-American ATP students. Rist observed that as the school year went on, the physical separation of the ATP students became more pronounced with almost all of them being separated from their classmates because of desk placement by their teachers or by placement in low academic achievement groups. In one particularly striking episode, Rist wrote:

My sense of Jeff's isolation from others in his room became more pervasive with each visit. Today, I entered the room and then turned to leave because I did not see Jeff. I asked the teacher, Mrs. Wills, if he was sick, and she said, no, he was over on the floor in the corner. He was lying face down, seemingly asleep. When I walked over to him, he looked up and smiled. He told me he was working on one of his puzzles, which was near by. 
When the teacher called for Jeff's reading group, Jeff did not respond, and Rist "found this interesting, for it indicated how separated Jeff had become from his reading group. When it was called, he moved not a muscle. The group no longer had significance for him, and he no longer considered himself a member. He belonged nowhere." Paradoxically, the parents of ATP students were satisfied that busing was providing their children with a better education, and all of the parents Rist interviewed said they would keep their children in the program. ${ }^{6}$

DESEGREGATION, ESPECIALLY AT Jefferson High School, continued to be a top priority for school administrators who feared federal sanctions, and they continually modified plans during the 1970s to meet desegregation goals. Jefferson High School was considered Portland's "Black" high school because of both its location in the Albina district and its high percentage of African-American students. Enrollment at Jefferson steadily declined during the 1960s and 1970s; reasons for the decline included a district boundary change in 1965, the opening of nearby Adams High School in 1969 (which resulted in another district boundary change), and the failure to capture incoming students from feeder schools. ${ }^{62}$

In 1971, some of PPS' top administrators circulated a confidential report, "Portland Schools and Integration — Some Alternatives" with further ideas for ending de facto segregation at Jefferson High School. The plan included seven alternatives, six of which involved clustering or pairing schools with busing to achieve racial integration. The seventh alternative was "closing Jefferson High School or making it an alternative facility." Realizing the unpopularity of busing Euro-American students, the school board chose option seven and changed Jefferson High School from a general curriculum high school to a magnet performing arts school in $1974 .{ }^{63}$ This change failed to reduce the percentage of minority students at Jefferson because too few Euro-American students were interested in transferring to the magnet program. By 1978, the new arts magnet program had attracted 124 new students. Ninety of those were Euro-American, but the total number of incoming students was not enough to reduce the racial imbalance at Jefferson High School. ${ }^{64}$

In 1975, the Oregon Legislature passed new guidelines defining any school with over a 50 percent minority population as racially isolated, and in the 1976-1977 school year, Jefferson High School exceeded that mark. ${ }^{65}$ The school board was forced to consider other methods to reduce Jefferson's minority student population. School board members met over the Christmas break to discuss their concern about racial distribution and isolation patterns, and Jonathan Newman voiced an opinion shared by others: "Unless we apply further remedies ourselves, we can eventually expect to be placed under 
a court decree." ${ }^{\prime 6}$ In 1977, Newman presented his plan: Boise Elementary and King Elementary students would be rerouted from their neighborhood high school, Jefferson, and redirected to Lincoln and Wilson high schools. Newman also suggested that minority populations within individual schools be limited to their overall district representation, which meant that since African-American students made up approximately 18 percent of the total student body, they should not exceed 18 percent at any particular school. Because the other high schools in inner-Northeast Portland that would normally receive African-American students already had more than 18 percent minority student populations - Adams 36.5 percent, Grant 31.1 percent, and Washington 23.5 percent - African-American students would be forced to travel to schools outside their attendance district. ${ }^{67}$

Up until that point, busing had been limited to elementary and middle school students, but the Newman Plan threatened busing for the high schools, a proposal that angered many of Albina's residents. The Portland Observer, an African-American newspaper, editorialized against the Newman Plan:

At no time has the white population been disturbed. At no time has there been "voluntary" forced busing of white students. We doubt that this "voluntary" busing of Blacks only would meet the requirements of the federal courts. But worst of all, there has never been any accountability to the Black community. ${ }^{68}$

The Boise School Advisory committee rejected the Newman Plan outright. They said they were not consulted about the plan before it was made public and that the plan discriminated against African-American students. At a public meeting about the Newman Plan, parents voiced concern that the burden of desegregation, especially busing, was falling only on AfricanAmerican students. One African American explained:

Why should our children be expected to do all of the desegregating? Why doesn't the community participate? Their children don't have to ride busses and face strange new schools where they are unknown and many times not wanted. I want my child to get the best possible education and if that means busing her across town I don't mind. But I think white parents should meet us half way. All they have been expected to do so far is to let us go to their schools. ${ }^{69}$

Such fierce community opposition to the Newman Plan forced the school board to back away from implementing it as originally written.

In the months after the Newman Plan was proposed, various groups investigated why racial imbalance existed at Jefferson High School, especially since its feeder schools were predominantly Euro-American because of Blanchard's redrawing of district boundaries as part of Schools for the 
Seventies. Approximately a month after the original proposal, the Portland Observer reported that Jefferson High School's problems were caused by parents from the feeder schools who deliberately ignored attendance district boundaries and sent their children to Benson, Monroe, or Roosevelt high school instead of Jefferson. The article notes:

Although a certain percentage of the feeder school graduates would "legitimately" go to Benson, Monroe, and other high schools to take advantage of special curricula, the coalition [of Jefferson High School parents] feels that a significant amount are escaping their geographically-designated school because of Jefferson's "assigned" reputation of being a "bad, Black school."”o

In 1970, for example, Jefferson High School's attendance area was approximately 28 percent minority, but that same year, the school's minority student body was 38.5 percent. ${ }^{71}$ While Benson and Monroe were also magnet schools (Jefferson became a magnet school in 1974), the Portland Observer posed a legitimate question in 1977 about whether all of the students admitted to the magnet schools were actually qualified to be there. Additionally, of the approximately 16 percent of the Jefferson High School feeder class lost to Benson, only one-tenth were minority students. ${ }^{72}$ According to another Observer article, if the school boundary attendance policy had been enforced, Jefferson's minority population would have been 27.78 percent minority in the 1976-1977 school year. When asked why PPS focused on busing rather than enforcing attendance boundaries, Blanchard cited a lack of enforcement resources. ${ }^{73}$

At a school board meeting about the proposed Newman Plan, Blanchard responded to complaints about desegregation and shifted the responsibility for desegregation back to the African-American community, further angering African-American attendees. A Portland Observer article quoted Herb Cawthorne, a future school board member, on Blanchard's remarks:

"The manner in which Dr. Blanchard opened the meeting was personally offensive and set a tone that I don't think was warranted. If that was not your intention - that is what happened." Stating that the district does not seem concerned about the people who have gone through thirteen years of desegregation he [Cawthorne] said it should not be surprising that people would be disgruntled. The impression given by Dr. Blanchard's statement was that "we were to be spanked and scorned." ${ }^{4}$

In the face of public protests, the school board passed a revised Newman Plan with a 30 percent minority quota, but it placed the onus on the African-American community to come up with other ways to reduce minority student isolation - a moot point considering the school board had already passed the plan..$^{75}$ 
African-American parents started organizing protests against busing in December 1977, and by January 1978, the school board had reversed its position on the Newman Plan. The Community Coalition for School Integration (CCSI), a broad coalition of various community organizations including the NAACP and the American Friends Service Committee, started its own investigation into desegregating Portland's public schools. In November 1978, the CCSI presented the school board with ideas for desegregation. Their main recommendation was to implement pairing of schools, which would distribute the burden of busing more equitably. Blanchard agreed with most of the coalition's findings, but he rejected pairing as "excessive." ${ }^{76} \mathrm{His}$ dismissive attitude angered members of the African-American community, and a rebellion against the Portland School Board gained intensity.

Ron Herndon, founder of the Black Educational Center, met with CCSI member Herb Cawthorne in the early summer of 1979 to discuss ways to address the school boards' intransigence regarding the needs of the AfricanAmerican community, and thus Portland's branch of the Black United Front (BUF) was born.77 The BUF called for a boycott of the school board for the fall of 1979, and they rapidly gained a broad spectrum of supporters. ${ }^{78}$ The goal of the BUF was to force the school board to change its policies: first, an end to all busing; second, establishment of at least one middle school in the Albina neighborhood named for a female African-American historical figure; third, keeping inner-Northeast high schools open. ${ }^{79}$ Other community groups joined BUF in its efforts to force change.

In 1979 and 1980, the power of the BUF in Portland's school issues was clearly visible. Three school board members left in 1978; two sought other political offices and one retired for personal reasons. Jonathan Newman, author of the Newman Plan, resigned under pressure in 1979, and all four replacement members were more partial to protestors' concerns and even included one of the BUF's founders, Herb Cawthorne. By the fall of 1979, the BUF was calling for Blanchard's dismissal. ${ }^{80}$ In a controversial vote the following year, Blanchard was fired. Various Portland business leaders responded by pushing for a recall of the four new school board members, all of whom had voted for Blanchard's dismissal. Blanchard also filed a lawsuit against the school board for wrongful termination. The BUF reacted by calling for a boycott of the businesses involved in the school board recall. The controversy ended when Blanchard unexpectedly died of a heart attack five months after his dismissal. ${ }^{{ }_{11}}$ With a new majority on the school board that was both receptive and responsive to the BUF's demands, the search for a superintendent began. The BUF was now leading the way on education issues in Portland. 
On April 14, 1980, after negotiations involving the BUF, the CCSI, and other concerned community members, PPS adopted the Comprehensive Desegregation Plan (CDP). The seven goals of the CDP were:

1. To avoid and eliminate inequitable compulsory burdens imposed by desegregation;

2. To increase desegregation and integration through equitable means;

3. To provide education which more fully meets the needs of each child;

4. To create an excellent multicultural/multiethnic education for all children;

5. To promote interracial acceptance and understanding among students and staff;

6. To increase educational choice for all children in the district; and

7. To comply with federal and state laws, policies, and regulations. ${ }^{82}$

The BUF played a significant role in the creation of this plan and signed off on the final version. Although PPS had up to that point manifested a pattern of resistance to change, with the publication of the CDP, many community members felt hopeful for the future. Steve Buell, a school board member from 1979 to 1983 , commented that, at the time, the plan "felt like a huge accomplishment." 83

\section{THE BLACK UNITED FRONT, SCHOOL CLOSURES, AND MULTICULTURALISM, 1981-1999}

After their initial success of ending busing for desegregation in Portland, the BUF changed its focus to keeping Jefferson High School open and creating and expanding multicultural curriculum within Portland's public schools; both issues continue to resonate almost thirty years later. It is unclear how much community support existed for multicultural curriculum. The fate of Jefferson High School, however, remained a flashpoint within the AfricanAmerican community, and its threatened closure gave the BUF a strong base of support. School board meetings were regularly boycotted by the BUF during the early 1980s, and the BUF moved into an uncomfortable position of being both an adversary of and working for PPS. ${ }^{84}$

Jefferson High School's enrollment had steadily declined during the 1960 s and 1970s, and in 1974, 1977, and 1980, the student body dipped below 1,000 total students. ${ }^{85}$ As mentioned previously, several factors were responsible for the enrollment declines, including the close proximity of other high schools, changes in attendance district boundaries, and PPS' failure to enforce attendance district boundaries. Another aspect affecting all Portland high schools was the city's changing demographics - there were fewer children attending public schools than during the post-war baby boom period. Converting Jefferson into an arts magnet school in 1974 had a marginal impact 
on Euro-American student enrollment, and PPS was left with several high schools that were significantly under capacity.

In the early 1980s, PPS identified for closure several schools with low enrollment, and once again, Jefferson was on the short list. Several student boycotts and BUF strikes had their intended effect and the school was saved. Adams and Washington-Monroe high schools were closed in 1981, sending approximately 500 new students to Jefferson. ${ }^{86}$ The school's negative reputation began to fade, and more students transferred to Jefferson for the arts magnet program. A gang-related shooting on the school's front steps in February 1988 once again painted it as a dangerous place, and enrollment declined. ${ }^{87}$ In the three years following the shooting, Jefferson lost over 400 students. $^{88}$

THE CDP, WHICH NOTABLY called for expanded multicultural curriculum, was a direct outgrowth of the controversies over busing and education during the previous decades and, at least initially, the school board and PPS were proactive in its implementation. Busing was ended, schools in inner-Northeast Portland remained open, Harriet Tubman Middle School was created, a Desegregation Monitoring and Activity Committee (DMAC) was established in 1980, the school board brought in Chief Desegregation Consultant Dr. Asa Hilliard in 1981, and the board hired Portland's first African-American school superintendent, Dr. Matthew Prophet, in 1982.

The CDP's goal of creating a multicultural curriculum was a major topic of discussion and contention within the Portland school system throughout the 1980 and 1990 . The plan originally designed Baseline Essays as the core of its multicultural curriculum, intending the essays to supplement existing school textbooks. All of the major minority and ethnic populations in the Western United States, including African Americans, Native Americans, Hispanic Americans, Asian Americans, and Pacific Islanders, were to have their own set of essays that covered six topics: art, literature, history, science, music, and mathematics. Hilliard was intimately involved with the writing of the essays, insisting that the authors be nationally recognized scholars and members of the ethnic group they were writing about; he even included his recommendations for the African American Baseline Essay authors. ${ }^{89}$ Both Hilliard and employees within PPS were making every effort to give the Baseline Essays legitimacy; Carolyn M. Leonard, the PPS contact for multicultural curriculum, insisted that the Baseline Essays be peer reviewed. ${ }^{\circ}$ Hilliard's goals were not fully realized, however, as not all of the scholars he identified were interested in writing African American Baseline Essays. Some of the writers therefore did not meet his initial criteria. While some he identified, such as historian John Henrik Clark, mathematician Beatrice Lumpkin, 


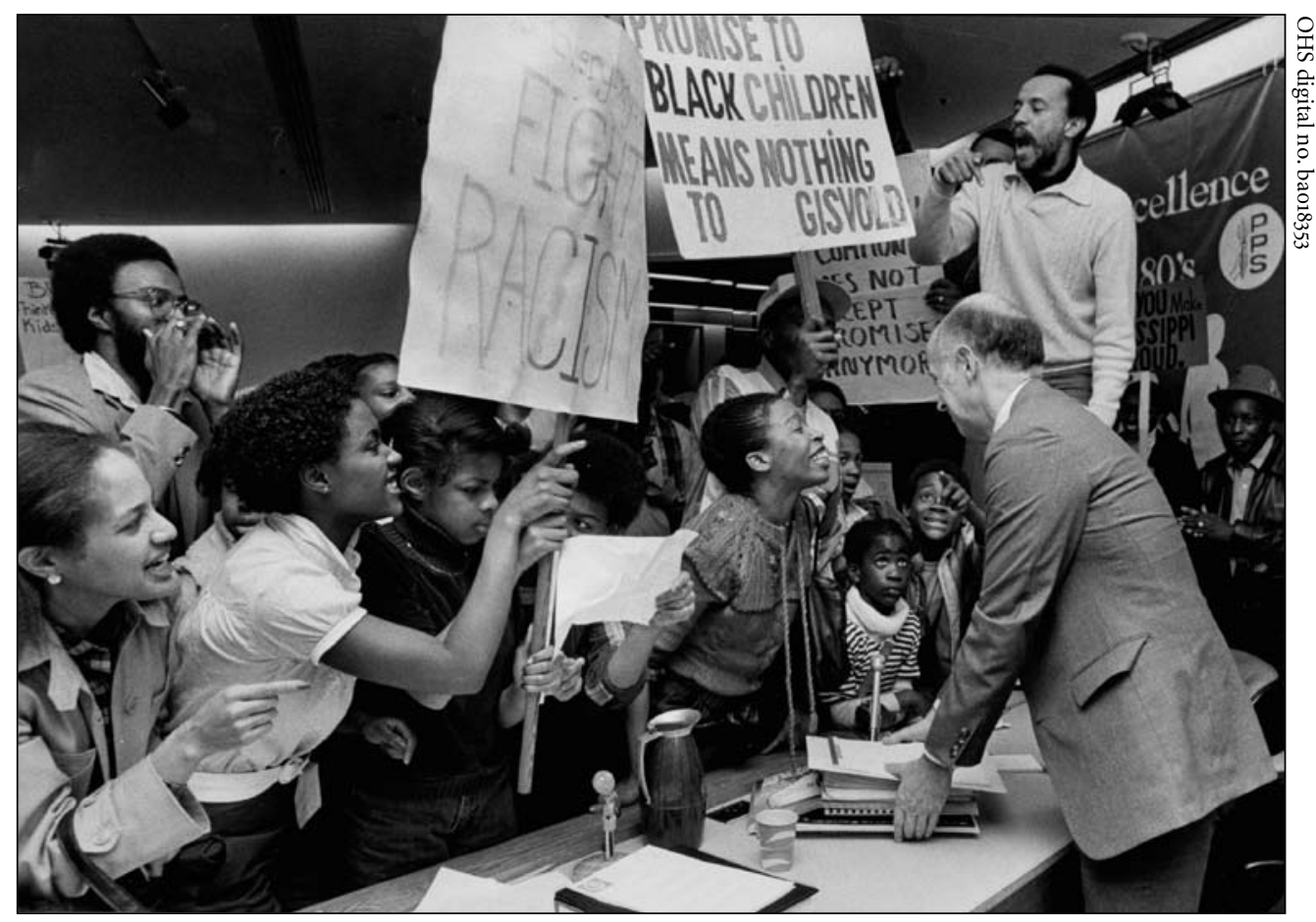

Ron Hendron stands on a table (in white sweater) at this 1982 BUF school board protest. At right, behind the table, is school board member James Fenwick. Protesters are angry about the placement of Harriet Tubman Middle School.

and art professor Michael D. Harris, were able to contribute, other Baseline authors lacked national prominence. Joyce Harris, author of the Literature African American Baseline Essay, was a Reed College graduate, one of the founders of the Black Educational Center, and a member of the BUF. Finding a science author proved especially challenging, and the BUF recommended Hunter Adams - a decision that would undermine the legitimacy of the Baseline Essays. In a later challenge to the essays, the Oregonian reported that Adams was an industrial hygiene technician, not a research scientist, and his highest educational attainment was a high school diploma. ${ }^{91}$

The conceptual framework of the Baseline Essays appears to have relied heavily on the model used by the Black Educational Center, an Afro-centric private school founded by Reed College alumni Ron Herndon, Frank Wilson, and Joyce Harris. The leadership of the Black United Front came directly from the center. The goal of the Black Educational Center was to teach African-American students about their culture and history while using innovative teaching techniques that encouraged students to learn and close 
the student achievement gap. According to Harris, the Black Educational Center was successful because it not only increased student achievement, it also provided a successful model "of education that was conceptualized and implemented by African Americans." ${ }^{22}$ The African American Baseline Essays were started in 1981, substantially revised in 1986, and were ready for classroom use by 1987. It seems that the BUF intended the Baseline Essays to be fully integrated into the public schools' curriculum, but PPS instead offered them only as an information resource for teachers, along with teacher training sessions and curriculum guides. ${ }^{93}$

Portland Public Schools' implementation of the multicultural/multiethnic education was largely inadequate. According to researcher Wanyoni Wambalaba, only two clusters, the Jefferson and Grant high school clusters, which had the majority of African-American students, received training on multicultural education. Of the teachers who received training, they reported that it was "sparse and not very useful." The Desegregation Monitoring Advisory Committee (DMAC), a citizen watchdog group that included members of the BUF, presented their annual report in 1988 and found that PPS failed to implement multicultural education, noting that no students had received instruction from the African American Baseline Essays. They also castigated PPS for failing to organize a systematic training approach for teachers or students. Ironically, as the DMAC's 1989 report noted, the African American Baseline Essays had been embraced nationally. ${ }^{94}$

Within Portland's public schools, many teachers and principals expressed support for multicultural education, even though some had reservations about the tone of the African American Baseline Essays. PPS gave principals and teachers a lot of leeway in implementing multicultural curriculum with the caveat that it had to be used in some way on a regular basis in their lesson planning, but principals noted that implementation was a problem. The Baseline Essays were one aspect of multicultural curriculum, but teachers were not required to use them, even though Marshall High School's principal referred to the African American Baseline Essays as "the best material of any district in the United States." ${ }^{95}$ One Oregonian article suggested that the Baseline Essays were not regarded as controversial by the teachers within PPS, but Wambalaba suggests that because the African American Baseline Essays were neither fully implemented nor required to be used within the classroom, resistance from Portland's predominantly Euro-American teaching staff will never be fully known. ${ }^{96}$ Wambalaba did find that there was resistance to the Baseline Essays from district administrators, which would account, at least in part, for the failure to require implementation. Teachers also were not evaluated on their classroom implementation of multicultural education. ${ }^{97}$ 
Understanding the media-driven controversy that erupted over the Baseline Essays requires connecting them to the national debates over history and literature in the United States. While there had been extensive discussion both within and outside academic circles leading up to 1992, the 5ooth anniversary and celebration of Christopher Columbus's voyage brought to the forefront a long simmering debate over Euro-centric history and the literary canon. With scholars and many minority and ethnic groups calling for a new examination of history, educational curriculum, especially in history and literature, faced an onslaught of criticism on the national level. Portland's Baseline Essays landed right in the middle of the controversy in part because they were one of the first systematic attempts by a school district in the United States to address multicultural education. ${ }^{98}$

The African American Baseline Essays gained notoriety on the local level in 1990, several years after they were first made available for classroom use. Oregonian columnist Steve Duin led the attack with his article "A Return to Segregationist History," in which he criticized the African American Baseline Essays for their "Afrocentric" view of history. The specific problems he mentioned were: Egypt was presented as an African and thus Black nation, the suggestion of cultural syncretism between long-cherished Western values and their possible African origins, and that African-American literature had been manipulated and controlled by Euro-American publishers. Duin referred to these as "desperate assertions" in the Baseline Essays that were "derided by more objective historians." He also referred to the tone of the essays as "hysterical," accusing them of obscuring the truth:

The Baseline Essays stress black culture at the expense of all others. They mix political statements with historical insights, and they resurrect segregationist history. Black culture suffered too long in the hands of white historians; now, someone, or something, else is going to suffer. Like the truth. ${ }^{99}$

While Duin did acknowledge that the presentation of African-American history had been unfair in the past, he refused to acknowledge any validity in the African American Baseline Essays. He also directly challenged the work of African-American historians, implying that Euro-American historians' opinions carried more weight. Duin wrote several other articles in the following years condemning the Baseline Essays. ${ }^{100}$ Another Oregonian columnist, David Reinhard, echoed Duin's sentiments, but Reinhard added to his criticism the "doubtful therapeutic aim of Afro-centric curricula" presented by the African American Baseline Essays and multicultural education. Reinhard referred to the essays as "feel-good, fallacy-filled history."

The national criticism of the African American Baseline Essays came from several angles. Anthropologist Bernard Ortiz de Montellano undermined the 
validity of the Science Essay because it failed to differentiate between religion and science, and he also attacked the credibility of its author, Hunter Adams. ${ }^{102}$ Historian Arthur Schlesinger, Jr., challenged the essays because of their potential for divisiveness and claimed that the purpose of the essays was therapeutic, writing in his book The Disuniting of America: "The use of history as therapy means the corruption of history as history." Schlesinger also defended Eurocentric history because the majority of Americans - he put the number at 80 percent - are of European descent and most of American history derived directly from European roots. ${ }^{103}$ Time magazine also condemned the essays because of their Afro-centrism and some strange relationship, never mentioned in the essays, between Afro-centric scholars and their alleged belief that melanin makes people of African descent superior. ${ }^{104}$

Many of the criticisms in the local and national media challenging the validity of the African American Baseline Essays were unfounded. Schlesinger's objections to "therapeutic" history embodied in the Baseline Essays were called into question by sociologist James Loewen's study of high school history textbooks, Lies My Teacher Told Me: Everything Your American History Textbook Got Wrong. Loewen points out that history textbooks originated in the nativist and nationalist period of the early twentieth century and were filled with history designed to make Euro-Americans feel good, often at the expense of minorities. ${ }^{105}$ Cultural syncretism has been substantiated by researchers, both from sub-Saharan Africa to Egypt and from Egypt to Greece. ${ }^{106}$

The media-driven furor surrounding the African American Baseline Essays took several twists, with some that clearly veered toward the absurd, like the melanin argument, but what is clear is that the only people defending the essays were a handful of former Portland School Board members, administrators, and the African-American scholars who wrote them. The controversy over the Baseline Essays continued for approximately four years, reaching its national peak in 1994. By that time, Portland had a new school superintendent, a new school board, and no desire to continue the fights over multiculturalism. The Baseline Essays were consigned to the PPS warehouse, where they sat gathering dust, and PPS instead focused its attention on funding, which had been threatened by the passage of Measure Five property tax limits.

The Comprehensive Desegregation Plan's broad purpose was to address the quality of education among minority students by introducing multicultural education and ending segregation in an equitable fashion. In a 1986 survey of student achievement, PPS noted that minority student test scores had gained an average of eleven points in four years, which was a substantial achievement. ${ }^{107}$ An Oregonian article from 1992 revealed similar results but tempered them with persistent failures to eliminate the gap completely, 
reporting that "the proportion of Portland black students performing above the national average increased by 56 percent in reading and 63 percent in math over the last decade. Even so, black student performance falls far below the district average." ${ }^{108}$ Portland's African-American students were achieving at a higher rate and multicultural education was gaining traction, but there was a price as Portland schools moved back towards segregation. ${ }^{109}$

IN 1867, PORTLAND Public Schools instituted its first and only experiment with officially segregating the schools, but only five years later, pressure from the Euro-American community over funding caused the closure of the Colored School and Portland Public Schools were officially desegregated. In the 140 years since then, PPS has continued to struggle with the core issues of the Colored School experience: the school board's desire not to alienate its Euro-American patrons, the persistence of the African-American community in fighting for a quality education for its children, and the implementation of policies that never fully addressed the concerns and needs of the African American community. All echoed throughout the twentieth century, and these issues continue to resonate today.

\section{NOTES}

We would like to thank several people who helped with the research for this paper, including Kelsey Decker, and the archivists from the Portland Public Schools, Melinda Murray and David Evans. They led us to rare sources, theses, and maps that added greatly to this paper, and it was a pleasure to work with them. A special thanks also goes to the editor of the $O H Q$, Eliza Canty-Jones, for her assistance with focusing our revisions and helping us bring this paper to publication.

1. Helen Marie Casey, Portland's Compromise: The Colored School, 1867-1872 (Portland, Ore.: Portland Public Schools Public Information Department, 1980), 5, 10. See also Local Color, DVD, directed by John Tuttle (Portland: Oregon Public Broadcasting, 1991), especially Ellen Law's description of sundown towns and Kathryn Bogle's story about a lynching the year she arrived in Marshfield (Coos Bay), Oregon.

2. Elizabeth McLagan, A Peculiar Paradise: A History of Blacks in Oregon, 1788-1940 (Port- land, Ore.: Georgian Press Company, 1980); City of Portland Planning Bureau, The History of Portland's African American Community (1805 to the Present) (Portland: 1993), 29-32.

3. There have been a series of dissertations on various aspects of PPS and its African-American students, including: Judith Helene Doyle, "Desegregation, Integration and the Charter of Portland Public Schools" (M.A. Thesis, Oregon State University, 1982); Elizabeth MacGregor Geddes, "Desegregation/ Integration - Policies and Practices: Portland Public Schools, Portland, Oregon, 1970-1981" (Ph.D. diss., Brigham Young University, 1982); Herbert Colby Grose, "Education and Equality in the Portland Public Schools," (M.A. Thesis, Reed College, 1973); Ronald Herndon, "Racism in the Portland Public Schools" (B.A. Thesis, Reed College, 1970); Bernard Raymond La Plante, "The Negro At Jefferson High School: A Historical Study of Racial Change" (Ph.D. diss., University of Oregon, 1970); Thomas Damian Rand-Luby, "The Controversy 
Over the Portland Public Schools' AfricanAmerican Baseline Essays, 1983-1992," (M.A. thesis, Portland State University, 1997); and Wanyoni Moses Wambalaba, "Factors Enhancing And/Or Inhibiting the Development and Implementation of the Baseline Essays within Portland Public Schools" (Ph.D. diss., Portland State University, 1999). See also Zaher Wahab, "The Portland Public School System: From Panacea to Battleground," Annual Meeting of the Comparative and International Education Society. Tallahassee, Florida, March, 1981.

4. City of Portland Bureau of Planning, The History of Portland's African American Community, 1.

5. Eugene H. Berwanger, The Frontier Against Slavery: Western Anti-Negro Prejudice and the Slavery Extension Controversy (Chicago: University of Illinois Press, 1967), 95.

6. Cheryl A Brooks, "The Politics of Forgetting: How Oregon Forgot to Ratify the 14th Amendment," Oregon Humanities (Fall/ Winter 2006), available http://www.oregonhum.org/politics-of-forgetting.php (accessed January 27, 2010).

7. William Toll, "Permanent Settlement: Japanese Families in Portland in 1920," The Western Historical Quarterly 28:1 (1997): 23.

8. Stuart McElderry, “The Problem of the Color Line: Civil Rights and Racial Ideology in Portland, Oregon, 1944-1965" (Ph.D. diss., University of Oregon, 1998), 25.

9. Quintard Taylor, The Forging of a Black Community: Seattle's Central District from 1870 through the Civil Rights Era (Seattle: University of Washington Press, 1994).

10. Brooks, "The Politics of Forgetting."

11. Tuttle, Local Color.

12. Karen J. Gibson, "Bleeding Albina: A History of Community Disinvestment, 1940-2000," Transforming Anthropology 15 (2007): 6 .

13. E. Kimbark MacColl, The Shaping of a City: Business and Politics in Portland, Oregon, 1885-1915 (Portland, Ore.: The Georgian Press, 1976), 137.

14. Kathryn Hall Bogle, "Document: Kathryn Hall Bogle's 'An American Negro Speaks of Color," Oregon Historical Quarterly 89:1
(Spring 1988): 70-81, quote at 78 .

15. Philip H. Parrish, Historic Oregon (New York: MacMillan Company, 1937); John B. Woods and Nelson S. Rogers, Your Oregon: Yesterday, Today, and Tomorrow (Portland, Ore.: Northwest Regional Council, 1942).

16. Gibson, "Bleeding Albina," 7.

17. "Court Action Voted to Block Housing Plan for Negroes," Oregonian, September 30 , 1942, p. 1.

18. McElderry, "The Problem of the Color Line," 139.

19. Stuart McElderry, "Building a West Coast Ghetto: African-American Housing in Portland, 1910-1960," Pacific Northwest Quarterly 92 (Summer 2001): 142.

20. McElderry, "The Problem of the Color Line," 124, 207; Ibid., 137-48.

21. Tuttle, Local Color, Mayor Earl Riley quote, approx. 28:55-29:04, Russell Peyton quote, approx. 29:00-31:18.

22. Gibson, "Bleeding Albina," 10.

23. Portland Development Commission, 1966 Urban Renewal Grant Application to the Department of Housing and Urban Development, R103:17.

24. City Club of Portland Report, "The Negro in Portland: A Progress Report 1945-57," E. Kimbark MacColl, Chair, 37 (1957), 368.

25. U.S. Department of Commerce, Bureau of the Census, U.S. Census of Population 1960: Standard Metropolitan Statistical Areas (Washington, D.C.: GPO, 1963), 246.

26. City Club of Portland Report, "Racial Integration-Desegregation Issue in the Portland Public Schools" Ron Lansing, Chair, 60 (1980): 337 .

27. "NAACP General Counsel Charges Portland Schools Segregated," Oregonian, April 21, 1962, p. 8.

28. "Portland NAACP Leader Sees Few Local Changes," Oregonian, October 7, 1964, p. 10; James Long, "Education Study Hit By Negro," Oregon Journal, October 7, 1964, p. 1.

29. John Guernsey, "Race Study Draws Fire" Oregonian, June 4, 1963, p. 16.

30. Race and Equal Educational Opportunity in Portland's Public Schools, Committee on Race and Education, Chair Herbert M. 
Schwab, (Portland, Ore.: Portland Public Schools, 1964) [hereafter Schwab Report]; "Portland NAACP Leader Sees Few Local Changes," Oregonian, October 7, 1964, p. 10.

31. Schwab Report, 147; La Plante, "The Negro At Jefferson High School,"183.

32. Schwab Report, 206.

33. Ibid., 209.

34. We use the cultural deficiency model as explored and defined by R.D. Hess and V.C. Shipman, "Early Experience and the Socialization of Cognitive Modes in Children," Child Development 36 (1965): 869-86.

35. Schwab Report, 16.

36. Ibid., 163.

37. William H. McClendon, Straight Ahead: Essays on the Struggle of Blacks in America, 1934-1994 (Oakland, Cal.: The Black Scholar Press, 1995), 141.

38. "Race, Education Report Probes Albina Environment," Oregon Journal, November 2, 1964, p. 9.

39. "Portland NAACP Chief Assails Racial Report," Oregonian, January 14, 1965, p. 33.

40. Schwab Report, 201.

41. City Club of Portland, "The Model Schools Program of School District No. 1.," 53 (1972).

42. Ibid., 9.

43. Ibid., 14; Gibson, "Bleeding Albina," 13.

44. "The Model Schools Program of School District No. 1," 10-11, 22.

45. Editorial, "Fix the Model Schools," Oregon Advance Times, May 2, 1968, p. 2.

46. City Club of Portland, "Problems of Racial Justice in Portland," Richard W. Nahstoll, Chair, 49 (1968), 16.

47. Enrollment Reports, Management Information Services, Portland Public Schools.

48. "Racial Strife Hits High School, Brings Complaints from Parents," Oregonian, November 7, 1964, p. 11; "Jeff High Officials Says Area-wide Drive Needed to Curb Race Rows Near School," Oregonian, September 21, 1966, p. 24; "New Jefferson Policy Aims at Racial Upsets," Oregon Journal, November 1, 1967, p. 6; "Charge of Bigotry Laid to Some Teachers at Jeff," Oregon Journal, November
8, 1967, p. 2.

49. "Jeff Shut Down By Unrest," Oregonian, April 6, 1968, p. 1.

50. Editorial, "About Face," Oregon Advance Times, April 11, 1968, p. 2; "Jeff Due Extra Policemen," Oregon Journal, April 10, 1968, p. 3; "Close Down Jeff? Demand Discipline?," Oregonian, April 27, 1969, p. $4 \mathrm{f}$.

51. "What the People Say," Oregon Advance Times, February 15, 1968, p. 5.

52. Editorial, "Problem Exists Here, Too," Oregon Advance Times, March 7, 1968, p. 2.

53. "Police, Witness, Participants Offer Explanations for Albina Disorders," and "Albina Dwellers Charge Police with Beatings, Harassment," Oregonian, June 17, 1969, p. 13.

54. Grose, "Education and Equality in the Portland Public Schools," 13-14.

55. Portland Public Schools Records Management, Accession No. 91-039, box 5, Department: District-Wide Programs DMAC - Historical Documents, "Preliminary Superintendent's Response to the Report and Recommendations of the Community Coalition for School Integration" by Robert Blanchard, December 11, 1978, p. 25-26.

56. Geddes, "Desegregation/Integration,"; Binder, Ref 370.19342 GED, available at PPS Records and Archives, Appendix A: Board Resolution $\mathrm{X}_{3553}$, "Portland Schools For the Seventies," March 23, 1970.

57. PPS Archives and Records, Dept: Superintendent, ccc: 402, Accession No. 82-012, Subject Files, Desegregation, 1975-78, box 1, folder 1, "Citizens Desegregation Coalition," CCSI Draft Memorandum from Herb Cawthorne and Dick Frey, August 31, 1978.

58. A Staff Report of the United States Commission on Civil Rights, School Desegregation in Portland, (Washington D.C.: GPO, 1977), 6. The numbers cited by the Staff Report do not match PPS' internal numbers, and we were unable to reconcile the data. Our purpose is to demonstrate that African-American students were overwhelmingly overrepresented in busing.

59. "Black Community Favors Busing," Oregon Advance Times, August 22, 1968, p. 1.

6o. Reverend W.G. Hardy interviewed by 
Jason Wilde, Portland, Oregon, November 19, 2008, archived at Portland State University Library in the PDX Civil Rights Project collection, 8-9.

61. Ray C. Rist, The Invisible Children: School Integration in American Society (Cambridge, Mass: Harvard University Press, 1978), 194-243, 241-43; Portland Public Schools Records Management, District-Wide Programs, ccc: 404.3, Accession No. 91-039, DMAC — Historical Documents - box 5, "History Racial Integration Programs for the Portland Public Schools” February 21, 1979, 12.

62. La Plante, "The Negro At Jefferson High School," 172.

63. Rist, The Invisible Children, 34-35.

64. Paul Pintarich, "Jeff Campaigns for

Area Enrollment," Oregonian, February 24, 1978, p. B7.

65. ORS 659.150.

66. Jonathan Newman's Memorandum, January 31, 1977, p. 13, PPS Archives and Records, Dept: Superintendent, ccc:402, Accession No. 82-012, Subject Files, Desegregation, 1975-78, box 1, folder Desegregation Planning, 1977.

67. "Desegregation Policy Excludes Blacks," Portland Observer, June 9, 1977, p. 1.

68. "The Racism of Neglect" Portland

Observer, June 16, 1977, p. 2.

69. "Community Rejects Racial Plan"

Portland Observer, June 16, 1977, p. 1.

70. "Jefferson Victim of White Flight"

Portland Observer, July 21, 1977, p. 1.

71. Ibid., p. 2; Geddes, "Desegregation/ Integration," 196.

72. "Jefferson Victim of White Flight,"

Portland Observer, July 21, 1977, p. 2; "Coalition Advises School Board: Enforce District Attendance Policy," Portland Observer December 15, 1977, p. 1; "Board considers King-Boise Plan," Portland Observer, January 5, 1978, p. 1.

73. "Board considers King-Boise Plan,"

Portland Observer, January 5, 1978, p. 1.

74. "Portland School Board Passes Third

Newman Plan" Portland Observer, July 28,

1977, pp. 1, 6.

75. Ibid.

76. "Racial Integration-Desegregation Is- sues in the Portland Public Schools," 339.

77. Ronald Herndon, interviewed by Jolanda Swain, May 13, 1988, archived at the Oregon Historical Society, Portland, tape 1, side 1, approx 054. Ron Herndon had come to Portland on a Rockefeller Scholarship to attend Reed College in the late 1960s. He was active in the takeover of Eliot Hall on the Reed Campus and was one of the founding members of the short-lived Reed College Black Studies Department. After graduating from Reed, Herndon and several other Reed College Black Studies alumni founded the Black Educational Center (BEC) in 1970. The BEC was initially an after-school and summer school program, but transitioned into a full-time private school in 1978. The BEC covered grades one through four and focused on teaching African-American history and culture. In 1977, the BEC had approximately thirty students enrolled. "Black Education Center," Portland Observer, May 19, 1977, p. 4.

78. "White Parents Support Black Student Boycott," Oregon Journal, August 27, 1979, p. 4.

79. Herndon interview, tape 1 , side 1 , approx 054 .

8o. "Blanchard Must Go Says BUF Head," The Skanner, November 28, 1979, p. 1.

81. Wahab, "The Portland Public School System," 17.

82. Portland Public Schools, Comprehensive Desegregation Plan (Portland, Ore.: Portland Public Schools Public Information Department, 1980), 7.

83. Beth Slovic, "School Colors," Willamette Week, November 17, 2007, http://www. wweek.com/editorial/3401/9965 (accessed February 28, 2008).

84. "Board to Seek Injunction," Oregonian, April 19, 1982, p. A1.

85. Enrollment Reports, Management Information Services, Portland Public Schools.

86. Huntly Collins "Jefferson Enrollment May Violate Guidelines" Oregonian, September 10, 1981, p. B8.

87. Barnes C. Eillis, "Shooter, 19, Gets 10-Year Prison Term," Oregonian, August 27, 1988, sec. B, p. 1. 
88. Portland Public Schools Records Management, Enrollment Reports, Management Information Services, Portland Public Schools.

89. Portland Public Schools Records Management, Accession No. 91-039, box 1, Department: District-Wide Programs — DMAC - Historical Documents, folder "Complete List of Recommendations by Dr. Hilliard," n.d., pp. 5, 8 .

90. Ibid.; Fran Gardner, "Black Studies Program Still Raising Questions," Oregonian, April 24, 1989, p. B1. Folder also contains working drafts of African American Baseline Essays with reviewers' comments.

91. David Reinhard, “Top Ten Problems with the Baseline Essays," Oregonian, April 16, 1994, p. D6.

92. Joyce Harris interview by Jessie Labrie, Portland, Oregon, November 13, 2008, archived at Portland State University in the PDX Civil Rights Project collection, p. 29.

93. Wambalaba, "Factors Enhancing And/Or Inhibiting the Development and Implementation of the Baseline Essays within Portland Public Schools," 287.

94. Ibid.,252, 242, 263, 265.

95. Suzanne Daley, "Inspirational Black History Draws Academic Fire," New York Times, October 10, 1990, p. A1; Fran Gardner, "Black Studies Program Still Raising Questions” Oregonian, April 24, 1989, p. B1.

96. Gardner, "Black Studies Program Still Raising Questions," Oregonian, April 24, 1989 .

97. Wambalaba, "Factors Enhancing And/Or Inhibiting the Development and Implementation of the Baseline Essays within Portland Public Schools," 343-45.

98. Ibid., 236, 239, 259.

99. Steve Duin, "A Return to Segregationist History," Oregonian, November 18, 1990, p. B1.

100. Steve Duin, "Temporarily Fogged or Fatally Tinted?," Oregonian, November 27, 1990, p. B5; Steve Duin, “Don't Read Huck Finn Out," Oregonian, November 30, 1990, p. C10; Steve Duin, "An Invitation You Should Not Refuse," Oregonian, February 13, 1992, p. B7.
101. David Reinhard, "Top 10 Problems with the Baseline Essays," Oregonian, April 16, 1994, p. D6.

102. Bernard Ortiz de Montellano, "Multicultural Pseudoscience: Spreading Scientific Illiteracy Among Minorities — Part 1," Skeptical Inquirer 16 (1991): 47.

103. Arthur M. Schlesinger, Jr., The Disuniting of America: Reflections on a Multicultural Society (New York: W.W. Norton, 1992), 52, 71, 93.

104. Leon Jaroff, "Teaching Reverse Racism” Time (April 4, 1994), 74-75.

105. James Loewen, Lies My Teacher Told Me: Everything Your American History Textbook Got Wrong (New York: New Press, 1995), chapters 12 and 13 .

106. David O'Connor, Ancient Nubia: Egypt's Rival in Africa (Philadelphia: University Museum of Archeology and Anthropology, University of Pennsylvania, 1993); Ivan Van Sertima, Egypt Revisited (New Brunswick, N.J.: Transaction Publishers, 1991); Roberta L. Shaw and Krztsztof A. Grzymski, Ancient Egypt and Nubia (Toronto: Royal Ontario Museum, 1994); Stanley M. Burstein, "When Greek Was an African Language: The Role of Greek Culture in Ancient and Medieval Nubia," Journal of World History 19 (2008): 41-62; Stanley M. Burstein, Graeco-Africana: Studies in the History of Greek Relations with Egypt and Nubia (New Rochelle, NY: A.D. Caratzas, 1994).

107. Assessment and Evaluation Program, Northwest Regional Educational Laboratory, p. 9, Portland Public Schools Records Management, Accession No. 91-039, box 1, Department: District-Wide Programs "A Statistical Portrait of the Multicultural/Multiethnic Student Population In Portland Public Schools: A Summary Report,” January 1986.

108. Bill Graves, "Educator Insists All Children Can Reach High Levels of Attainment," Oregonian, October 31, 1992, p. B4.

109. "Portland Schools Quietly Moving Towards Resegregation," Oregonian, April 14, 1985, p. C2; Clifton R. Chestnut and Steven Carter, "Schools Grow More Segregated," Oregonian, December 5, 2001, p. C1. 